\title{
Authoritarianism and American Students' Attitudes About the Gulf War, 1990-1996
}

\author{
Richard M. Doty \\ David G. Winter \\ University of Michigan \\ Bill E. Peterson \\ Smith College \\ Markus Kemmelmeier \\ University of Michigan
}

Studies with several different groups of students over the period from October 1990 to spring 1996 show a consistent set of relationships between right-wing authoritarianism (RWA) and aggressive support for U.S. policy during the Persian Gulf crisis and Gulf War. Before the war, high-RWA scorers endorsed more aggressive responses (including the use of nuclear weapons) to hypothetical Iraqi actions. After the war, they expressed relatively more gloating and less regret and, in retrospect, endorsed more aggressive hypothetical U.S. policies. Overall, their opinions tended to be low in complexity, high in certainty, and brief.

$\mathbf{I}_{\mathrm{n}}$ this article, we present the results of several studies of American college students to explore the relationship between authoritarianism and attitudes toward the 19901991 Persian Gulf crisis and Gulf War, from the time of the crisis and war itself through the spring of 1996. Our results add to the nomological network of the authoritarianism construct, while providing a vivid illustration of the role of personality factors in organizing and shaping political attitudes.

\section{AUTHORITARIANISM AND SUPPORT FOR AGGRESSION}

For over 50 years, the concept of authoritarianism (Adorno, Frenkel-Brunswik, Levinson, \& Sanford, 1950; Stagner, 1936) has provided an important framework for understanding relationships between personality and attitudes about a wide variety of social and political issues (see Winter, 1996, chap. 7). Recently, Altemeyer (1981, 1988) argued that the authoritarian syndrome has three basic elements: conventionality, acceptance of authority, and aggression. Winter (1996, chap. 7), reviewing the original conceptualization of authoritarianism by Adorno et al. (1950), suggested that these three themes actually may arise from a more fundamental sense of threat, which arouses intolerance of ambiguity, which leads to the differentiation or splitting of "good" leaders and "bad" enemies, finally permitting the "good" to punish the "bad" (pp. 228-231).

Many studies suggest that authoritarianism is associated with ethnocentrism, prejudice, and moralistic hostility toward unconventional points of view and behaviors, including people with AIDS, the homeless, drug users, and environmentalists (Peterson, Doty, \& Winter, 1993; see also Meloen, 1993, for a general review). People scoring high in authoritarianism want to restrict access to abortion (Sturman \& Doty, 1992). They believe that the United States should remain vigilant regarding changes in Eastern Europe, and they want to crack down on the Japanese for perceived unfair trade policies ( $\mathrm{Pe}$ terson et al., 1993). Finally, they support traditional gender roles, are critical of feminists and people who violate these roles, and personally express more tradi-

Authors' Note: An earlier version of some of the material in this article was presented at the August 1992 annual meeting of the International Society of Political Psychology in San Francisco. We are indebted to Ted Sturman for assistance in administering questionnaires and coding open-ended responses and to Richard Densel III, Laura Zettel, and Randi Rabinowitz for administering questionnaires. Finally, we are grateful to three anonymous reviewers for their helpful comments and suggestions. Address correspondence to David G. Winter, Department of Psychology, University of Michigan, 525 E. University Avenue, Ann Arbor, MI 48109-1109, e-mail dgwinter@umich.edu.

$P S P B$, Vol. 23 No. 11, November 1997 1133-1143

C) 1997 by the Society for Personality and Social Psychology, Inc. 
tional gender-role identities (Duncan, Peterson, \& Winter, 1997).

During the Vietnam War, authoritarianism was positively correlated with endorsement of U.S. involvement and support for invading North Vietnam (Izzett, 1971) and negatively correlated with participating in antiwar protests and other forms of activism (Granberg \& Corrigan, 1972). Such attitudes and preferences resonate with the themes of obedience, conventionality, and aggression that characterize the authoritarian personality (Altemeyer, 1981, 1988; Winter, 1996, chap. 7).

On the basis of the Vietnam War studies, we would expect authoritarianism to be positively correlated with condemnation of Iraq and support for U.S. President George Bush's Desert Shield and Desert Storm policies during the 1990-1991 Persian Gulf crisis and Gulf War. The American and allied cause should have appealed to the characteristic authoritarian themes of obedience, conventionality, and aggression.

On the other hand, the Gulf crisis and the Vietnam conflict were not completely comparable. American involvement in Vietnam developed gradually, lacked clearly defined military goals, and was controversial. In contrast, President Bush's August 5, 1990, declaration that the Iraqi invasion of Kuwait "will not stand," as well as the later troop deployments, air attacks, and ground invasion, met with widespread (although not unanimous) public approval. In the week following the Iraqi invasion, for example, over $80 \%$ of the American public favored sending U.S. troops to the region. This approval remained above $60 \%$ through mid-November 1990 (Gallup \& Newport, 1990, p. 13). Just days before the January 15,1991 , U.S. deadline for Iraqi withdrawal from Kuwait, $55 \%$ of the public supported an allied attack, even though they believed it would be a costly venture. ${ }^{1}$ Following the rapid allied victory in the ground war, President Bush had a record $89 \%$ approval rating ("Bush Approval," 1991, pp. 2-3). Although there was an antiwar movement, its influence never approached that of the Vietnam protests 25 years earlier, perhaps because during the Gulf War, the military exercised tight control over the news media.

With such a high level of popular support for the administration policies, there might be little scope for any additional effect due to personality factors in individuals. Alternatively, it is conceivable that people high in right-wing authoritarianism (RWA) might have been drawn to obey conservative leaders such as Pat Buchanan (1991), Jeane Kirkpatrick, and Edward Luttwak, who opposed Bush's policy and argued instead for an isolationist U.S. stance (Cramer, 1990) ${ }^{2}$ Conceivably, the ethnocentric moralism characteristic of authoritarianism could even have led to disapproval of the politics and extravagant lifestyle of the Kuwaiti ruling elite. Finally, the issues of anti-Arab prejudice, Israel's vulnerability, and the involvement of the United Nations as a partner in U.S. policy might have further complicated any simple effect of authoritarianism on attitudes about the crisis. Thus, although a positive relationship between authoritarianism and support for U.S. government policy was perhaps the most plausible hypothesis, it was by no means the obvious or only one.

\section{OVERVIEW OF SAMPLES}

\section{Participants}

To study the role of authoritarianism in organizing Gulf War attitudes, we administered a series of attitude and opinion questionnaires to various samples of college students at different points during and after the Gulf crisis and Gulf War. We first collected data in early October 1990 from a sample of 109 students (83 women and $26 \mathrm{men}$ ) in an upper level undergraduate psychology course at the University of Michigan (Sample A; tested in class). This was just over 2 months after the Iraqi invasion of Kuwait. At that time, no one knew whether the crisis would be resolved by diplomatic activity or would escalate to war. As the U.S. commitment intensified in autumn 1990, we queried other groups of students (Sample B; 95 women and 75 men), drawn from another upper level undergraduate psychology course (tested in class) and from the subject pool of introductory psychology courses (tested in small groups).

We tested other groups of students from the subject pool of the introductory psychology courses at three critical points during and after the war: in late January 1991, shortly after the air war had begun (Sample C; 21 women and 16 men); in March 1991, shortly after the end of the ground war (Sample D; 17 women and 20 men); and in April 1992, over 1 year after the end of the war (Sample E; 25 women and 12 men).

Finally, as a part of other research, we tested two groups of students from the introductory psychology pool well after the war: in the autumn of 1995 (Sample F; 62 women and 63 men) and in the spring of 1996 (Sample G; 55 women and 53 men). (The latter group was tested several months before the September 1996 Iraqi attacks on Kurdish territory that disrupted U.S. efforts to overthrow Saddam Hussein and elicited U.S. missile and air attacks.)

In all cases, student participation was voluntary, and anonymity was assured by having no identifying information on the response forms. In-class studies were carried out by graduate students not connected with the course. Because of missing data on particular items, the actual $N$ for any particular analysis may vary downward from the figures reported above for each sample. 


\section{Instruments}

Right-wing authoritarianism. Samples A through E were given a 30-item balanced measure of RWA, which has become the most widely used measure of the authoritarianism construct (Altemeyer, 1981, 1988). ${ }^{3}$ Because of time limitations, Samples $F$ and $G$ were given the 10 -item abbreviated RWA scale developed by Haddock, Zanna, and Esses (1993), who report a correlation of .89 between this measure and the 30-item version (p. 1108). Beyond that, different instruments were used with different samples, as described below.

Policy grid. Samples A and B were given a policy grid (see the appendix). Eight rows of the grid indicated the following possible Iraqi actions, each presumed to represent an increasing level of threat to American interests and allied forces: (a) Iraq leaves Kuwait; (b) Iraq does not leave Kuwait by June 30, 1991; (c) Iraq does not let U.S. and other hostages ${ }^{4}$ go by June 30, 1991; (d) Iraq executes U.S. and other hostages; (e) Iraq attacks Israel; (f) Iraq invades Saudi Arabia; (g) Iraq uses chemical weapons in an invasion of Saudi Arabia; and (h) Iraq invades Saudi Arabia and overwhelms U.S. and other defending forces. Seven columns were labeled with the following possible U.S./UN responses, each presumed to represent an increasing level of aggression: (a) withdraw all forces, (b) withdraw most forces, (c) use forces to defend Saudi Arabia only, (d) use forces to defend Saudi Arabia and recapture Kuwait, (e) attack Iraq on land only, (f) attack and bomb Iraq, and (g) attack Iraq and use nuclear weapons. In the data analysis, these seven policy options were assigned the values 1 through 7 , respectively, to represent increasing aggressiveness of response.

For each possible Iraqi action, participants were asked to check the column(s) of the allied response(s) they favored. (More than one column could be checked.) The grid was realistic: In autumn 1990, all of these Iraqi actions and allied responses seemed to be real possibilities. In addition to examining the aggressiveness of response to each hypothetical Iraqi action, we also derived four summary measures from this grid. The mean of all responses checked for all Iraqi hypothetical actions was the average force level favored. The number of the most aggressive response checked across the eight Iraqi actions was the maximum force level favored. Finally, whether participants checked the "use nuclear weapons" response to any Iraqi action gave a binary measure of any nuclear response favored, whereas the number of Iraqi actions for which an allied nuclear response was checked provided a more continuous measure of number of times a nuclear response was favored.

Open-ended measures. Using a variety of open-ended measures, each tailored to the diplomatic-military situ- ation at the time of testing, we tried to elicit a broader and more textured expression of students' opinions in Samples A, C, D, and E. These open-ended measures were always preceded by a brief summary of the crisis (war) to date. For example, the following summary was given to Sample A:

On August 2, 1990, Iraqi military forces invaded Kuwait. More recently, Iraqi President Saddam Hussein has proclaimed that Kuwait is and will remain a part of Iraq. In response, United States President Bush has sent American troops to Saudi Arabia, in coordination with military forces of other nations, and the Security Council of the United Nations has passed several resolutions condemning the Iraqi action.

In Sample A, participants were then asked to respond as follows:

Different people have different reactions to this situation. What are your feelings about it? That is, how do you feel about the Iraqi occupation and annexation of Kuwait? How do you feel about the U.S. and UN responses? What should be done? And how would you personally like to see the situation resolved?

Please express your feelings and opinions, in any way you like, in the space below.

Participants were then given about two thirds of a lined page for their response.

Sample C participants were given a similar openended measure, suitably updated to reflect the first 2 weeks of the air war and the imminent possibility of a ground war. Sample D participants, tested shortly after the end of the ground war, were asked to give their personal interpretation of events, as follows:

In the last eight months, there was an international crisis that led to war in the Persian Gulf. Different people have different perspectives on "what happened." In the space below, please describe the "story" of these events in your own words. What were the origins of the crisis? What really happened? What has been the result?

Don't worry about details you don't know or can't remember. We are interested in your personal version and interpretation of these events.

On the next page, they were asked, "How do you personally feel about the result you described on the previous page? What do you think U.S. policy should be in the future?"

Similarly, Sample E participants, tested over 1 year after the war, were asked to describe in their own words the "story" of the Gulf crisis and war. The following is an example of a typical response to this question, in April 1992: 
We invaded because we felt that the future of our oil trade was in jeopardy \& because Hussein was "over-stepping" his bounds in America. The result of this war was to show that we, the U.S., will follow through on our proposals and we are a force to be reckoned with. The situation now is fine.

Retrospective policy preferences. In 1995-1996, Samples F and $\mathrm{G}$ were asked to express their retrospective agreement or disagreement with U.S. Gulf War policies by evaluating eight actions the United States could have done but did not do during and after the war. After reading a brief summary of the crisis and war, participants were asked to do the following:

Imagine that you could go back to the time of the Iraq-Kuwait crisis and the Gulf War (1990-1991), but with today's perspective and knowing what you now know. What changes would you recommend in President Bush's policy? For each of the possible policy changes mentioned below, circle the appropriate number to indicate whether you would recommend it.

Using 9-point scales ranging from definitely not recommend this to definitely recommend this, participants then evaluated the following eight hypothetical actions:

Avoid war by relying on economic sanctions

Avoid the devastating effects on Iraqi people by not bombing civilian targets in Iraq

Avoiding the slaughter of Iraqi troops by not bombing their retreat from Kuwait

More U.S. military support for dissident groups (e.g., the Kurds in northern Iraq) to break away

More complete military destruction of Iraqi armed forces and military capability

Capture Saddam Hussein so as to try (and execute) him for war crimes

More thorough destruction of Iraq by more intensive bombing

Use of nuclear weapons against Iraq

\section{Coding of Open-Ended Measures}

In all, six variables were coded from the open-ended measures; however, certain variables were relevant only at certain times, as indicated in the variable descriptions below. Coding was done by the first author and a graduate-student colleague, without knowledge of participants' RWA scores. For the four variables described below, interscorer agreement was .90 or above (agreement on presence of the category; see Smith, 1992, p. 529), with differences resolved by discussion. The objective nature of the conceptual complexity and length variables made calculation of interscorer agreement unnecessary.

Policy agreement (coded in Sample A and C responses only). The principal hypothesis of the present research is that authoritarianism is related to agreement with, and support for, U.S. policy in the Gulf War. To measure policy agreement, we developed the following 5-point scale:

1 = Strong opposition to U.S. policy, with no mention of alternative responses. Examples:

I think we should bring the troops home now.

It's none of our business.

The U.S. should stop sticking its nose in. . .

2 = Disagreement with U.S. policy, particularly the military buildup. Support for alternative nonmilitary policies, such as continued economic sanctions or boycott. Examples:

The boycott is OK, but we shouldn't be sending all those troops.

I think Bush is wrong; let the UN handle it.

3 = Ambivalence, lack of information, or support for U.S. policy tempered with caution or skepticism. Examples:

Something had to be done, but I'm not sure we're doing the right thing.

The U.S. response is justified, but we're just there to protect our oil supply.

Let's keep the pressure on but not escalate.

4 = Support for U.S. policy, without qualification or caution but without mention of escalation. Examples:

The U.S. is totally correct.

I think Bush is doing the right thing.

Hopefully, there will be peace, but I agree with our sending the forces there.

5 = Strong support for U.S. policy, along with threats or a desire for escalation. Examples:

We should go to war as soon as we are ready.

We should turn Iraq into a parking lot.

Uncertainty (coded in Sample $A$ and $C$ responses only). People scoring high in authoritarianism are often thought to have (or prefer) a high level of certainty about the world (see Frenkel-Brunswik, 1949; Sorrentino \& Short, 1986). We measured participants' uncertainty by the presence of phrases such as "I don't know" or "I am really unsure" or expressions of skepticism. We hypothesized that this measure would be negatively related to RWA.

Gloating (coded in Sample $D$ and $E$ responses only). We expected that people scoring high in authoritarianism would be particularly impressed and pleased with the U.S. and allied performance in the war, glorifying the victory and exaggerating the implications of the results. We therefore scored responses such as the following for glorification or gloating:

Elaboration of the ease, quickness, or extent of U.S. military victory or of the consequences for Iraq

Explicit description of superiority of U.S. forces or weapons

Description of positive effects of the war on U.S. image or prestige 
Regret (coded in Sample $D$ and $E$ responses only). If people scoring high in authoritarianism glorify war and military victory, then people scoring low in authoritarianism should be more likely to express regret about the war or its effects (such as casualties or environmental damage). Examples include the following:

What a waste, think of all the lives that were lost and the environmental damage that was done-and for what, money \& power! How disgusting!

When I saw the faces of injured Iraqi children, innocent faces, I hated our world. It upsets me so much that war exists.

Conceptual complexity. Many theorists have suggested a negative relationship between cognitive complexity and authoritarianism, especially in situations in which people are evaluating or debating prospective policies (for example, Edgington \& Hutchinson, 1990; Sidanius, 1985, 1988; Suedfeld, Bluck, Loewen, \& Elkins, 1994; Tetlock, 1983). Because the present responses were usually too brief to apply the integrative complexity measure developed by Suedfeld and his associates (Suedfeld, Tetlock, \& Streufert, 1992), we relied instead on a simpler measure of conceptual complexity used by Hermann (1987), in which the number of high-complexity words (for example, maybe, possibly, and for example) is divided by the total of high-complexity and low-complexity words (for example, always, simply, and never). Although the Hermann and Suedfeld measures are conceptually similar, there are (to our knowledge) no studies reporting the correlation between the two. $\mathrm{Nu}$ merous studies by Hermann (1980a, 1980b, 1983, 1984) and others (e.g., Snare, 1992), however, do suggest that the two measures may have a common theoretical basis and similar construct validities. (Conceptual complexity scores were calculated only for responses with two or more scorable words.) This measure was applied to the open-ended responses written before the war (Samples A and C), as well as the March 1991 and April 1992 postwar samples (Samples D and E).

Length of response. Length of response, defined simply as the number of words in an open-ended response, was a dependent variable of interest in its own right. However, variations in length could create spurious relationships between RWA and other dependent variables, such as conceptual complexity or uncertainty. For example, if longer responses receive higher scores on complexity and uncertainty, then a relationship between RWA scores and any one of these variables might be an artifact of a relationship to either of the other two variables. In such cases, any effects of length can be controlled statistically.
RESULTS

\section{RWA Descriptive Statistics}

Means for the 30-item RWA measure were as follows: ${ }^{5}$ $90.11(S D=24.59)$ in Sample A; $97.30(S D=25.17)$ in Sample B; $102.00(S D=25.97)$ in Sample C; $100.11(S D=$ 23.91) in Sample D; and 104.73 ( $S D=21.51)$ in Sample E. These averages are consistent with those found in previous studies at the University of Michigan (see Duncan \& Stewart, 1995; Peterson et al., 1993). For the 10-item RWA measure, means were as follows: $4.68(S D=1.22)$ in Sample F, and 4.38 ( $S D=1.20)$ in Sample G. There was no significant gender difference on RWA score in any of the seven samples, although the mean score for men was higher than that for women in six of the samples.

\section{RWA and Policy Grid Options}

Table 1 presents descriptive statistics for the variables derived from the policy grid used with Samples A and B. In general, the level of aggression of response was related to the presumed level of threat of the hypothetical Iraqi actions as predicted, with two exceptions. In both samples, students apparently perceived an Iraqi invasion of Saudi Arabia and an Iraqi attack on Israel as less of a threat (that is, calling for a less aggressive U.S./UN response) than Iraqi execution of U.S. hostages. For these students, at least, the level of perceived threat seems to have been affected more by the nationality of the target of an action by a potential enemy (the United States versus Saudi Arabia or Israel) than by the actual military magnitude of the action (deaths of a few hundred people versus a full-scale invasion or attack).

In Sample A, there were no significant gender differences in scores on these policy options, but in Sample B, men favored a significantly more aggressive response to every hypothetical Iraqi action, as shown in the table.

Table 2 shows the relationship between RWA scores and the policy grid measures. In Sample A, tested in early October 1990, RWA was significantly associated with aggressiveness of response to three of the eight hypothetical Iraqi actions. In Sample B, tested a few weeks later, six of the eight correlations were significant. Thus, it appears that as the crisis deepened, RWA continued to play an important role in organizing specific attitudes and policy preferences. At both times, however, RWA was significantly related to all four summary measures, as shown in the last four rows of the table. It is especially noteworthy that RWA was associated with the two measures endorsing the use of nuclear weapons.

There were only a few significant gender differences in the magnitude of these relationships between RWA and aggressiveness of response: two in Sample A (one higher among men, one higher among women) and two in Sample B (both higher among men). 
TABLE 1: Descriptive Statistics for Variables Drawn From Policy Grid of Hypothetical Iraqi Actions and U.S./UN Responses

\begin{tabular}{|c|c|c|c|c|c|c|}
\hline \multirow[b]{3}{*}{ Level of Force Favored If: } & \multicolumn{6}{|c|}{ Mean (and Standard Deviation) } \\
\hline & \multicolumn{3}{|c|}{ Sample A (October 1990) } & \multicolumn{3}{|c|}{ Sample B (Late Autumn 1990) } \\
\hline & $\underset{(n=109)}{A l l}$ & $\begin{array}{c}M e n \\
(\mathrm{n}=26)\end{array}$ & $\begin{array}{l}\text { Women } \\
(\mathrm{n}=83)\end{array}$ & $\begin{array}{c}A l l \\
(\mathrm{n}=169)\end{array}$ & $\begin{array}{c}\text { Men } \\
(\mathrm{n}=75)\end{array}$ & $\begin{array}{l}\text { Women } \\
(\mathrm{n}=94)\end{array}$ \\
\hline Iraq leaves Kuwait $^{1}$ & $\begin{array}{l}1.98 \\
(0.90)\end{array}$ & $\begin{array}{c}2.15 \\
(1.16)\end{array}$ & $\begin{array}{c}1.93 \\
(0.80)\end{array}$ & $\begin{array}{c}1.99 \\
(0.87)\end{array}$ & $\begin{array}{l}2.20_{\mathrm{a}} \\
(0.95)\end{array}$ & $\begin{array}{r}1.83_{\mathrm{a}} \\
(0.77)\end{array}$ \\
\hline Iraq does not leave Kuwait by June $1991^{1}$ & $\begin{array}{c}3.83 \\
(0.94)\end{array}$ & $\begin{array}{c}3.88 \\
(0.88)\end{array}$ & $\begin{array}{c}3.81 \\
(0.97)\end{array}$ & $\begin{array}{l}3.70 \\
(1.47)\end{array}$ & $\begin{array}{r}4.07_{\mathrm{a}} \\
(1.45)\end{array}$ & $\begin{array}{c}3.4_{\mathrm{a}} \\
(1.42)\end{array}$ \\
\hline Iraq does not release hostages ${ }^{1}$ & $\begin{array}{l}4.40 \\
(1.07)\end{array}$ & $\begin{array}{l}4.38 \\
(1.06)\end{array}$ & $\begin{array}{c}4.40 \\
(1.08)\end{array}$ & $\begin{array}{c}4.17 \\
(1.54)\end{array}$ & $\begin{array}{r}4.49_{\mathrm{a}} \\
(1.62)\end{array}$ & $\begin{array}{r}3.93_{\mathrm{a}} \\
(1.43)\end{array}$ \\
\hline Iraq executes U.S. hostages ${ }^{1}$ & $\begin{array}{l}5.36 \\
(0.93)\end{array}$ & $\begin{array}{c}5.44 \\
(0.92)\end{array}$ & $\begin{array}{c}5.33 \\
(0.94)\end{array}$ & $\begin{array}{c}5.22 \\
(1.24)\end{array}$ & $\begin{array}{r}5.63_{\mathrm{a}} \\
(1.09)\end{array}$ & $\begin{array}{r}4.89_{\mathrm{a}} \\
(1.26)\end{array}$ \\
\hline Iraq attacks Israel $^{1}$ & $\begin{array}{l}5.27 \\
(1.04)\end{array}$ & $\begin{array}{c}5.42 \\
(1.02)\end{array}$ & $\begin{array}{c}5.21 \\
(1.05)\end{array}$ & $\begin{array}{c}4.97 \\
(1.54)\end{array}$ & $\begin{array}{r}5.344_{\mathrm{a}} \\
(1.44)\end{array}$ & $\begin{array}{r}4.68_{\mathrm{a}} \\
(1.57)\end{array}$ \\
\hline Iraq invades Saudi Arabia ${ }^{1}$ & $\begin{array}{c}4.81 \\
(1.11)\end{array}$ & $\begin{array}{c}5.04 \\
(1.17)\end{array}$ & $\begin{array}{c}4.74 \\
(1.09)\end{array}$ & $\begin{array}{c}4.62 \\
(1.42)\end{array}$ & $\begin{array}{r}5.10_{\mathrm{a}} \\
(1.39)\end{array}$ & $\begin{array}{r}4.266_{\mathrm{a}} \\
(1.34)\end{array}$ \\
\hline $\begin{array}{l}\text { Iraq invades Saudi Arabia and uses } \\
\text { chemical weapons }\end{array}$ & $\begin{array}{c}5.62 \\
(1.00)\end{array}$ & $\begin{array}{c}5.73 \\
(0.92)\end{array}$ & $\begin{array}{c}5.58 \\
(1.03)\end{array}$ & $\begin{array}{c}5.53 \\
(1.42)\end{array}$ & $\begin{array}{r}5.79_{\mathrm{a}} \\
(1.32)\end{array}$ & $\begin{array}{r}5.33_{\mathrm{a}} \\
(1.46)\end{array}$ \\
\hline $\begin{array}{l}\text { Iraq invades Saudi Arabia and } \\
\text { overwhelms U.S. forces }\end{array}$ & $\begin{array}{l}5.81 \\
(1.09)\end{array}$ & $\begin{array}{c}5.92 \\
(1.12)\end{array}$ & $\begin{array}{c}5.77 \\
(1.09)\end{array}$ & $\begin{array}{c}5.50 \\
(1.81)\end{array}$ & $\begin{array}{r}5.88_{\mathrm{a}} \\
(1.59)\end{array}$ & $\begin{array}{r}5.21_{\mathrm{a}} \\
(1.92)\end{array}$ \\
\hline Average force level favored & $\begin{array}{l}4.46 \\
(0.90)\end{array}$ & $\begin{array}{c}4.70 \\
(0.61)\end{array}$ & $\begin{array}{c}4.39 \\
(0.97)\end{array}$ & $\begin{array}{c}4.45 \\
(1.04)\end{array}$ & $\begin{array}{l}4.77_{\mathrm{a}} \\
(1.05)\end{array}$ & $\begin{array}{r}4.19 \mathrm{a} \\
(0.95)\end{array}$ \\
\hline Maximum force level favored & $\begin{array}{l}5.79 \\
(1.16)\end{array}$ & $\begin{array}{c}6.00 \\
(0.85)\end{array}$ & $\begin{array}{c}5.73 \\
(1.25)\end{array}$ & $\begin{array}{c}6.02 \\
(1.06)\end{array}$ & $\begin{array}{r}6.18 \mathrm{a} \\
(1.10)\end{array}$ & $\begin{array}{r}5.89 \mathrm{a} \\
(1.01)\end{array}$ \\
\hline Any nuclear response favored & $19 \%$ & $23 \%$ & $17 \%$ & $27 \%$ & $38 \%$ & $19 \%$ \\
\hline Number of times nuclear response is favored ${ }^{2}$ & $\begin{array}{c}.29 \\
(0.68)\end{array}$ & $\begin{array}{c}.27 \\
(0.54)\end{array}$ & $\begin{array}{c}.29 \\
(0.72)\end{array}$ & $\begin{array}{c}.52 \\
(1.16)\end{array}$ & $\begin{array}{r}.84 \mathrm{a} \\
(1.55)\end{array}$ & $\begin{array}{r}.27 \mathrm{a} \\
(0.62)\end{array}$ \\
\hline
\end{tabular}

NOTE: Means having a common subscript show a male-female difference significant at the .05 level or less.

1. Force-level ratings of hypothetical U. S./UN responses could range from 1 to 7 ; higher numbers indicate increasing aggressiveness of response.

Each participants' score is the mean force-level rating of all responses to a hypothetical Iraqi action that were checked.

2. Across all eight hypothetical Iraqi actions.

TABLE 2: Relation of Right-Wing Authoritarianism (RWA) Scores to Levels of Force Favored in Response to Hypothetical Iraqi Actions

\begin{tabular}{|c|c|c|}
\hline \multirow[b]{2}{*}{ Level of Force Favored If: } & \multicolumn{2}{|c|}{ Correlation With RWA } \\
\hline & $\begin{array}{c}\text { Sample A } \\
\text { (October 1990) } \\
(n=107)\end{array}$ & $\begin{array}{c}\text { Sample B } \\
\text { (Late Autumn 1990) } \\
(n=170)\end{array}$ \\
\hline Iraq leaves Kuwait & -.08 & .11 \\
\hline $\begin{array}{l}\text { Iraq does not leave Kuwait } \\
\text { by June } 1991\end{array}$ & $.21 * * *$ & $.20 * * * *$ \\
\hline Iraq does not release hostages & $.23 * * *$ & $.17 * * *$ \\
\hline Iraq executes U.S. hostages & .15 & $.24 * * * *$ \\
\hline Iraq attacks Israel & .11 & $.21 * * * *$ \\
\hline Iraq invades Saudi Arabia & -.05 & $.18^{* * *}$ \\
\hline $\begin{array}{l}\text { Iraq invades Saudi Arabia and } \\
\text { uses chemical weapons }\end{array}$ & -.04 & $.20 * * * *$ \\
\hline $\begin{array}{l}\text { Iraq invades Saudi Arabia and } \\
\text { overwhelms U.S. forces }\end{array}$ & $.20 * * *$ & .11 \\
\hline Average force level favored & $.22 * * *$ & $.26+$ \\
\hline Maximum force level favored ${ }^{a}$ & $.30 * * * *$ & $.22 * * * *$ \\
\hline Any nuclear response favored & $.31 \dagger$ & $.16^{* * *}$ \\
\hline $\begin{array}{l}\text { Number of times nuclear } \\
\text { response is favored }\end{array}$ & $.33 \dagger$ & $.18 * * *$ \\
\hline
\end{tabular}

a. Across all eight hypothetical Iraqi actions.

$* * * p<.05$, two-tailed. $* * * * p<.01$, two-tailed. $\dagger p<.001$, two-tailed.

\section{Open-Ended Measures}

Table 3 presents descriptive statistics for all variables derived from the open-ended responses. Overall, most students supported U.S. policy. In October 1990 (Sample A), the modal response was scored for agreement (39\%), although almost as many students expressed some ambivalence or reservations along with their agreement (33\%). Only $5 \%$ wanted to escalate, whereas $19 \%$ expressed disagreement and 3\% express strong opposition. In January 1991 (Sample C), the distribution was similar. There were no significant gender differences. Overall, these results suggest that the students in our samples held approximately the same views as the rest of the U.S. population (see the polling results described above).

Not surprisingly, uncertainty was higher in mid-January (just before the air war) than in October, and conceptual complexity was slightly lower. Both trends were especially true for women. After the war, a substantial proportion of the students expressed some gloating (46\% in March 1991 and $35 \%$ in April 1992). About half expressed a sense of regret (49\% in March 1991 and 54\% in April 
TABLE 3: Descriptive Statistics for Open-Ended Responses

\begin{tabular}{|c|c|c|c|}
\hline Sample and Variable & $A l l$ & Men & Women \\
\hline \multicolumn{4}{|l|}{ Sample A (October 1990) } \\
\hline$n$ & 94 & 23 & 71 \\
\hline Policy agreement-mean (and $S D$ ) & $3.24(0.94)$ & $3.30(0.82)$ & $3.23(0.97)$ \\
\hline Uncertainty & $23 \%$ & $17 \%$ & $25 \%$ \\
\hline Length-mean (and $S D$ ) & $74.15(32.68)$ & $69.17(28.94)$ & $75.79(32.56)$ \\
\hline Complexity-mean (and $S D$ ) & $.47(.25)$ & $.51(.28)$ & $.45(.25)$ \\
\hline \multicolumn{4}{|l|}{ Sample C (January 1991) } \\
\hline$n$ & 37 & 16 & 21 \\
\hline Policy agreement-mean (and $S D$ ) & $3.59(0.90)$ & $3.81(0.75)$ & $3.43(0.98)$ \\
\hline Uncertainty & $65 \%$ & $44 \%_{\mathrm{a}}$ & $81 \%_{\mathrm{a}}$ \\
\hline Length-mean (and $S D$ ) & $152.19(57.24)$ & $151.13(41.83)$ & $153.00(67.71)$ \\
\hline Complexity-mean (and $S D$ ) & $.38(.21)$ & $.38(.16)$ & $.38(.24)$ \\
\hline \multicolumn{4}{|l|}{ Sample D (March 1991) } \\
\hline$n$ & 37 & 20 & 17 \\
\hline Gloating & $46 \%$ & $65 \%_{\mathrm{a}}$ & $24 \%_{\mathrm{a}}$ \\
\hline Regret & $49 \%$ & $50 \%$ & $47 \%$ \\
\hline Length-mean (and $S D$ ) & $222.65(65.71)$ & $229.60(54.00)$ & $214.47(78.22)$ \\
\hline Complexity-mean (and $S D$ ) & $.47(.24)$ & $.46(.25)$ & $.48(.22)$ \\
\hline \multicolumn{4}{|l|}{ Sample E (April 1992) } \\
\hline$n$ & 37 & 12 & 25 \\
\hline Gloating & $35 \%$ & $50 \%$ & $28 \%$ \\
\hline Regret & $54 \%$ & $42 \%$ & $60 \%$ \\
\hline Length-mean (and $S D$ ) & $137.81(62.96)$ & $131.33(58.73)$ & $140.92(65.83)$ \\
\hline Complexity-mean (and $S D$ ) & $.46(.24)$ & $.40(.29)$ & $.50(.21)$ \\
\hline
\end{tabular}

NOTE: Percentages having a common subscript are significantly different at the .05 level or less.

TABLE 4: Relation of Right-Wing Authoritarianism (RWA) Scores to Characteristics of Open-Ended Responses

\begin{tabular}{lcccc}
\hline & \multicolumn{4}{c}{ Correlation With RWA Score } \\
\cline { 2 - 5 } $\begin{array}{l}\text { Response } \\
\text { Characteristic }\end{array}$ & $\begin{array}{c}\text { Sample A } \\
(\text { October 1990) } \\
(\mathrm{n}=94)\end{array}$ & $\begin{array}{c}\text { Sample C } \\
\text { (January 1991) } \\
(\mathrm{n}=37)\end{array}$ & $\begin{array}{c}\text { Sample D } \\
\text { March 1991) } \\
(\mathrm{n}=37)\end{array}$ & $\begin{array}{c}\text { Sample E } \\
(\text { April 1992) } \\
(\mathrm{n}=37)\end{array}$ \\
\hline $\begin{array}{l}\text { Policy } \\
\text { agreement }\end{array}$ & $.40 \dagger$ & $.59 \dagger$ & & \\
$\begin{array}{l}\text { Uncertainty } \\
\text { Gloating }\end{array}$ & -.16 & $-.34^{* * *}$ & & \\
$\begin{array}{l}\text { Regret } \\
\text { Conceptual } \\
\text { complexity }\end{array}$ & $-.27^{* * *}$ & -.12 & $.35^{* * *}$ & $.35^{* * *}$ \\
\begin{tabular}{l} 
Length \\
\hline
\end{tabular} & $-.30^{* * * *}$ & $-.46^{* * * *}$ & -.20 & -.15 \\
\hline
\end{tabular}

${ }^{*} p<.15$, two-tailed. ${ }^{* * *} p<.05$, two-tailed. ${ }^{* * * *} p<.01$, two-tailed. $\dagger p<$ .001 , two-tailed.

1992). There were only a few significant gender differences: Women expressed more uncertainty immediately before the air war (Sample C), whereas men gloated more immediately after the war (Sample E).

The relationships between RWA scores and the variables coded from the open-ended responses are shown in Table 4. Even with the relatively restricted range of policy-agreement scores ( $72 \%$ with scores of 3 or 4$)$, RWA was strongly and significantly associated with the degree of support for U.S. policy before the war actually started. After the war, people scoring high in RWA were more inclined to gloat and less inclined to express regret. (The latter result was only a trend, suggesting that even people scoring high in authoritarianism may not always be immune to regret: As one high scorer put it in April 1992, "the U.S. military overdid it.") Finally, at almost all time periods, RWA was associated with relatively simple thinking (lower conceptual complexity), lower uncertainty, and brief judgments (shorter responses). Although there were some significant gender differences in the pattern of all these relationships in the different samples, none held up consistently across samples. All of these relationships are consistent with the predictions derived from previous research on authoritarianism in general and on the RWA measure in particular.

Two artifactual explanations for these effects can be largely ruled out. One such artifact, length of response, is unlikely to be a contaminating factor because it was virtually uncorrelated with conceptual complexity and uncertainty (average $r=.086$ ). Thus, partialing out the effects of length did not change the relationship of RWA to complexity (average partial $r=-.18$ ) and uncertainty (average partial $r=-.19$ ), and partialing out the effects of complexity and uncertainty did not change the relationship of RWA to length (average partial $r s=-.26$ and -.35 , respectively) ${ }^{6}$

On the other hand, the relationships between RWA and the open-ended variables could have been affected by policy agreement. Some studies (e.g., Gruenfeld, 
TABLE 5: Descriptive Statistics for Retrospective Recommendations of Hypothetical U.S. Actions

\begin{tabular}{|c|c|c|c|c|c|c|}
\hline \multirow[b]{3}{*}{ In Retrospect, Would Recommend: } & \multicolumn{6}{|c|}{ Mean (and Standard Deviation) } \\
\hline & \multicolumn{3}{|c|}{ Sample F (Autumn 1995) } & \multicolumn{3}{|c|}{ Sample G (Spring 1996) } \\
\hline & $\begin{array}{c}A l l \\
(\mathrm{n}=125)\end{array}$ & $\begin{array}{c}\text { Men } \\
(\mathrm{n}=63)\end{array}$ & $\begin{array}{l}\text { Women } \\
(\mathrm{n}=62)\end{array}$ & $\begin{array}{c}A l l \\
(\mathrm{n}=108)\end{array}$ & $\begin{array}{c}\text { Men } \\
(\mathrm{n}=53)\end{array}$ & $\begin{array}{l}\text { Women } \\
(\mathrm{n}=55)\end{array}$ \\
\hline Avoid war by relying on economic sanctions & $\begin{array}{c}5.03 \\
(1.90)\end{array}$ & $\begin{array}{r}4.26_{\mathrm{a}} \\
(2.00)\end{array}$ & $\begin{array}{r}5.79_{\mathrm{a}} \\
(1.46)\end{array}$ & $\begin{array}{c}5.07 \\
(2.01)\end{array}$ & $\begin{array}{r}4.34_{\mathrm{a}} \\
(2.07)\end{array}$ & $\begin{array}{r}5.78_{\mathrm{a}} \\
(1.70)\end{array}$ \\
\hline $\begin{array}{l}\text { Avoid the devastating effects on Iraqi people } \\
\text { by not bombing civilian targets in Iraq }\end{array}$ & $\begin{array}{c}6.56 \\
(2.31)\end{array}$ & $\begin{array}{r}6.05_{\mathrm{a}} \\
(2.47)\end{array}$ & $\begin{array}{r}7.06_{\mathrm{a}} \\
(2.04)\end{array}$ & $\begin{array}{c}6.31 \\
(2.33)\end{array}$ & $\begin{array}{r}5.74_{\mathrm{a}} \\
(2.50)\end{array}$ & $\begin{array}{r}6.85_{\mathrm{a}} \\
(2.02)\end{array}$ \\
\hline $\begin{array}{l}\text { Avoiding the slaughter of Iraqi troops by } \\
\text { not bombing their retreat from Kuwait }\end{array}$ & $\begin{array}{c}6.01 \\
(2.20)\end{array}$ & $\begin{array}{c}5.66 \\
(2.30)\end{array}$ & $\begin{array}{l}6.35 \\
(2.06)\end{array}$ & $\begin{array}{c}6.05 \\
(2.07)\end{array}$ & $\begin{array}{l}5.49_{\mathrm{a}} \\
(2.13)\end{array}$ & $\begin{array}{r}6.588_{\mathrm{a}} \\
(1.88)\end{array}$ \\
\hline $\begin{array}{l}\text { More U.S. military support for dissident } \\
\text { groups (e.g., the Kurds in northern Iraq) } \\
\text { to break away from Iraq and establish }\end{array}$ & & & & & & \\
\hline independent nations & $\begin{array}{c}5.41 \\
(1.99)\end{array}$ & $\begin{array}{c}5.13 \\
(2.27)\end{array}$ & $\begin{array}{c}5.68 \\
(1.64)\end{array}$ & $\begin{array}{c}5.12 \\
(1.99)\end{array}$ & $\begin{array}{c}4.92 \\
(1.95)\end{array}$ & $\begin{array}{c}5.31 \\
(2.04)\end{array}$ \\
\hline $\begin{array}{l}\text { More complete military destruction of Iraqi } \\
\text { armed forces and military capability }\end{array}$ & $\begin{array}{c}5.26 \\
(2.35)\end{array}$ & $\begin{array}{r}5.822_{a} \\
(2.45)\end{array}$ & $\begin{array}{l}4.69_{\mathrm{a}} \\
(2.13)\end{array}$ & $\begin{array}{c}5.40 \\
(2.27)\end{array}$ & $\begin{array}{l}5.87_{\mathrm{a}} \\
(2.18)\end{array}$ & $\begin{array}{r}4.95 \mathrm{a} \\
(2.28)\end{array}$ \\
\hline $\begin{array}{l}\text { Capture Saddam Hussein so as to try (and } \\
\text { execute) him for war crimes }\end{array}$ & $\begin{array}{c}5.98 \\
(2.28)\end{array}$ & $\begin{array}{r}6.53_{\mathrm{a}} \\
(2.18)\end{array}$ & $\begin{array}{r}5.44_{\mathrm{a}} \\
(2.26)\end{array}$ & $\begin{array}{c}5.76 \\
(2.51)\end{array}$ & $\begin{array}{c}6.17 \\
(2.39)\end{array}$ & $\begin{array}{c}5.35 \\
(2.58)\end{array}$ \\
\hline $\begin{array}{l}\text { More thorough destruction of Iraq by more } \\
\text { intensive bombing }\end{array}$ & $\begin{array}{l}3.53 \\
(2.12)\end{array}$ & $\begin{array}{r}4.15_{\mathrm{a}} \\
(2.27)\end{array}$ & $\begin{array}{l}2.92_{\mathrm{a}} \\
(1.79)\end{array}$ & $\begin{array}{l}3.23 \\
(1.79)\end{array}$ & $\begin{array}{c}3.49 \\
(1.98)\end{array}$ & $\begin{array}{c}2.98 \\
(1.56)\end{array}$ \\
\hline Use of nuclear weapons against Iraq & $\begin{array}{c}2.16 \\
(1.96)\end{array}$ & $\begin{array}{c}2.26 \\
(2.08)\end{array}$ & $\begin{array}{c}2.06 \\
(1.85)\end{array}$ & $\begin{array}{c}1.52 \\
(1.20)\end{array}$ & $\begin{array}{c}1.36 \\
(1.06)\end{array}$ & $\begin{array}{c}1.69 \\
(1.31)\end{array}$ \\
\hline
\end{tabular}

NOTE: Mean ratings could range from 1 to 9; higher numbers indicate greater support of recommendation. Means having a common subscript are significantly different at the .05 level or less.

1995) have found that people's integrative complexity is higher when they are writing in opposition rather than agreement. Thus, in the present case, students scoring high in RWA may have written less complex, shorter, and less uncertain responses about U.S. policy simply because they were writing in agreement with it. In both Samples A and C, partialing out the effect of policy agreement left the negative correlations between RWA and length virtually unchanged (partial $r s=-.30$ and -.40 , respectively), but it did reduce the negative correlation between RWA and uncertainty virtually to zero (partial $r \mathrm{~s}=-.03$ and .01 , respectively). Thus, the apparent relationship of RWA to uncertainty may be an artifact of policy agreement.

In summary, then, we can say that students scoring high in RWA were certain about their agreement with U.S. policy about the Gulf crisis and war. Apart from that agreement, their responses were also brief, and apart from that brevity, they were also relatively simple.

\section{Retrospective Policy Preferences}

Table 5 presents the descriptive statistics for the retrospective policy preference measures obtained in
1995-1996. If the value of 5 (midpoint on the 9-point scale) can be taken as representing a neutral position between definitely recommend and definitely not recommend, then the overall results suggest that the students would, looking back, recommend a slightly less aggressive U.S. policy in the Gulf War. There was, however, a gender difference: In both Samples F and G, men were more likely than women to recommend aggressive policies and less likely to recommend nonaggressive policies.

Table 6 presents the relationship between RWA scores and retrospective policy recommendations. Although the magnitude and significance levels of the correlations are slightly different in the two samples, the overall results are consistent. Students scoring high in RWA are more likely to recommend aggressive policies-those involving greater destruction of Iraqi armed forces and infrastructure, and the capture of Saddam Hussein. These relationships between RWA and retrospective preferences were in the same direction for women and men but perhaps slightly stronger among women $(r$ greater for women in four of the seven correlations in Sample F and in six of seven in Sample G). 
TABLE 6: Relation of Right-Wing Authoritarianism (RWA) Scores to Retrospective Recommendations of Hypothetical U.S. Actions

\begin{tabular}{|c|c|c|}
\hline \multirow[b]{2}{*}{ In Retrospect, Would Recommend: } & \multicolumn{2}{|c|}{ Correlation With RWA } \\
\hline & $\begin{array}{c}\text { Sample F } \\
\text { (Autumn 1995) } \\
(n=125)\end{array}$ & $\begin{array}{c}\text { Sample G } \\
\text { (Spring 1996) } \\
(\mathrm{n}=108)\end{array}$ \\
\hline $\begin{array}{l}\text { Avoid war by relying on } \\
\text { economic sanctions }\end{array}$ & $-.21 * * *$ & $-.25 * * *$ \\
\hline $\begin{array}{l}\text { Avoid the devastating effects on } \\
\text { Iraqi people by not bombing } \\
\text { civilian targets in Iraq }\end{array}$ & $-.27 * * * *$ & -.05 \\
\hline $\begin{array}{l}\text { Avoiding the slaughter of Iraqi } \\
\text { troops by not bombing their } \\
\text { retreat from Kuwait }\end{array}$ & $-.19 * * *$ & -.14 \\
\hline $\begin{array}{l}\text { More U.S. military support for } \\
\text { dissident groups (e.g., the } \\
\text { Kurds in northern Iraq) to break } \\
\text { away from Iraq and establish }\end{array}$ & & \\
\hline independent nations & .04 & .10 \\
\hline $\begin{array}{l}\text { More complete military } \\
\text { destruction of Iraqi armed } \\
\text { forces and military capability }\end{array}$ & $.26 * * * *$ & $.32 * * * *$ \\
\hline $\begin{array}{l}\text { Capture Saddam Hussein so as } \\
\text { to try (and execute) him for } \\
\text { war crimes }\end{array}$ & .11 & $.25 * * * *$ \\
\hline $\begin{array}{l}\text { More thorough destruction of Iraq } \\
\text { by more intensive bombing }\end{array}$ & $.16^{* *}$ & $.26 * * * *$ \\
\hline Use of nuclear weapons against Iraq & .09 & -.02 \\
\hline
\end{tabular}

\section{DISCUSSION AND CONCLUSIONS}

\section{Right-Wing Authoritarianism and Politics}

Taken together, the results obtained from these seven samples suggest that the RWA measure is related to uncomplicated and continuing support for an aggressive U.S. policy in the Persian Gulf crisis and GulfWar. People scoring high in RWA agreed with their government's tough approach to Iraq during the crisis leading up to the war and during the war itself. In response to a range of hypothetical Iraqi actions, they favored relatively more aggressive U.S./UN responses. After the war, they expressed a sense of gloating rather than regret, and as much as 5 years later endorsed even higher levels of aggression than the U.S. actually used. Their support for the use of nuclear weapons (at least prospectively in 1990, if not retrospectively in 1995-1996)-in a hypothetical scenario (U.S. forces overwhelmed) that was extreme but not unimaginable-seems especially ominous, given a future with increased nuclear proliferation and other types of unconventional threat. In their openended opinions, high scorers display lower conceptual complexity, have less to say, and are more certain about what they have said.
These results confirm previous findings relating authoritarianism to avoidance of uncertainty, obedience to authorities, and a punitive, aggressive attitude toward out-groups. More broadly, the results suggest that authoritarianism continues to be a valuable construct for exploring the relationship between personality and attitudes about international conflict and other situations likely to engage ethnocentrism and prejudice (see Meloen, 1993). Although differences among the samples make it difficult to interpret these results in terms of changes over time, and small sample sizes may have made some results unstable, the results taken as a whole do suggest that the effects of RWA on attitudes about specific political events endure for several years.

\section{Right-Wing Authoritarianism, Gender Differences, and Masculinity}

The conclusion that RWA is related to aggressive attitudes and policy preferences is, to be sure, hardly new and scarcely surprising. However, focusing on the way in which gender is involved in our results may suggest (albeit tentatively) an expanded theoretical understanding of the dynamics of RWA, and thus new directions for future research. Let us begin with a summary of the gender differences observed in the present study. Although the overall patterns of relationship between RWA and the various dependent variables held true for both women and men, the average levels of almost all dependent variables showed gender differences. Men tended to be "hawks": They supported more aggressive U.S./UN responses, both in prospect and in retrospect, and they gloated more after the victory. Women, in contrast, tended to be "doves": They supported alternatives to aggression or lower levels of aggression, and they felt more uncertainty and regret. (Not all these differences were statistically significant, in part because of small sample sizes, but the overall pattern is clear; see Tables 1, 3, and 5.) Taken together, this pattern of gender differences is consistent with widespread and pervasive gender-role stereotypes about tough-minded and aggressive men and tender-minded, uncertain, and regretful women.

One way of summarizing our results, therefore, is that among both women and men, RWA has the effect of moving attitudes and opinions toward the stereotype of masculinity. Yet, such a summary needs immediate qualification: Making war (as well, perhaps, as making of political decisions about war) is almost exclusively a domain of men (Elshtain, 1987). Because the relevant attitude objects (President Bush, Saddam Hussein, U.S./UN and Iraqi military leadership and troops) were either exclusively or predominantly male, women scoring high in RWA may have been endorsing aggressive 
sentiments and policies as guides for men's actions rather as guides for their own actions.

Even further qualification is in order: Although explicit war making may be almost exclusively a male activity, women are in fact highly "present" in warfare - as an enthusiastic "audience" (Canetti, 1962, especially pp. 132-141), as victims of sexualized violence and violent sexuality (Brownmiller, 1992; Rank, 1914), or as weeping widows and mothers (Shevin-Coetzee \& Coetzee, 1995, pp. 16-22). War and aggression, in short, are activities that seem designed to emphasize or enhance traditional sex roles. (Ironically, this may be only a short-run effect, for in the long run, the economic demands and male casualties of war may work against traditional sex roles.) Thus, the present findings concerning RWA may be one facet of a general tendency for RWA to be associated with the maintenance and exaggeration of traditional sex roles (aggression for men, tenderness for women), as Duncan, Peterson, and Winter (1997) have found with respect to other gender-related issues. This interpretation is admittedly speculative, but if it is confirmed by further studies involving RWA, gender and gender roles, and aggression, then our understanding of the nature and dynamics of authoritarianism would be considerably broadened and deepened.
In the social constructionist view, gender is inevitably an ambiguous category. Thus, a general intolerance of ambiguity (arguably the core of authoritarianism) would most clearly and obviously be reflected in concerns to maintain unambiguous and enduring gender(ed) boundaries: lines in the sand-lines between nation-states and (thus) lines between men and women.

\section{NOTES}

1. Thus, a few days earlier, only $6 \%$ believed that American deaths would be fewer than 1,000 (see "Buildup to War," 1991, pp. 6, 8).

2. Thus, Cramer (1990) characterized the language of these rightwing skeptics as "reminiscent of Vietnam-era protests" and quotes a foreign policy expert that " 'these folks were all for our actions overseas [but only] as long as there was a communist target' " (p. 27).

3. We used a 7-point scale instead of the usual 9-point scale used by Altemeyer (1981, 1988).

4. These were the several thousand foreign nationals in Iraq and Kuwait at the time of the invasion, who were detained by Iraq during most of the fall of 1990 .

5. Because 7-point scales (ranging from 1 to 7) were used for the 30-item measure and because scores on the 10-item measure were expressed in terms of mean item score (on a 1- to 9-point scale), these means cannot be compared with each other or to the original 9-point right-wing authoritarianism(RWA) scales used by Altemeyer (1981, 1988).

6. Because the Hermann measure is essentially a ratio, it tends to be uncorrelated with length (average $r=.086$, as noted above), in

\section{APPENDIX \\ Policy Grid Used in Samples A and B}

In the left-hand column below is a list of some different things that could happen in the Persian Gulf situation. In the right-hand columns are possible United States and United Nations responses. For each thing that could happen, please check the U.S./UN response(s) that you would favor in those circumstances. (For each row, try to check the single response you favor most, but you may check more than one if you can't decide or aren't sure.)

If you want to explain or comment on any of the situations and choices, you can write on the back of this page.

If this happens:

Then I favor this U.S./UN response:

(please check as appropriate)

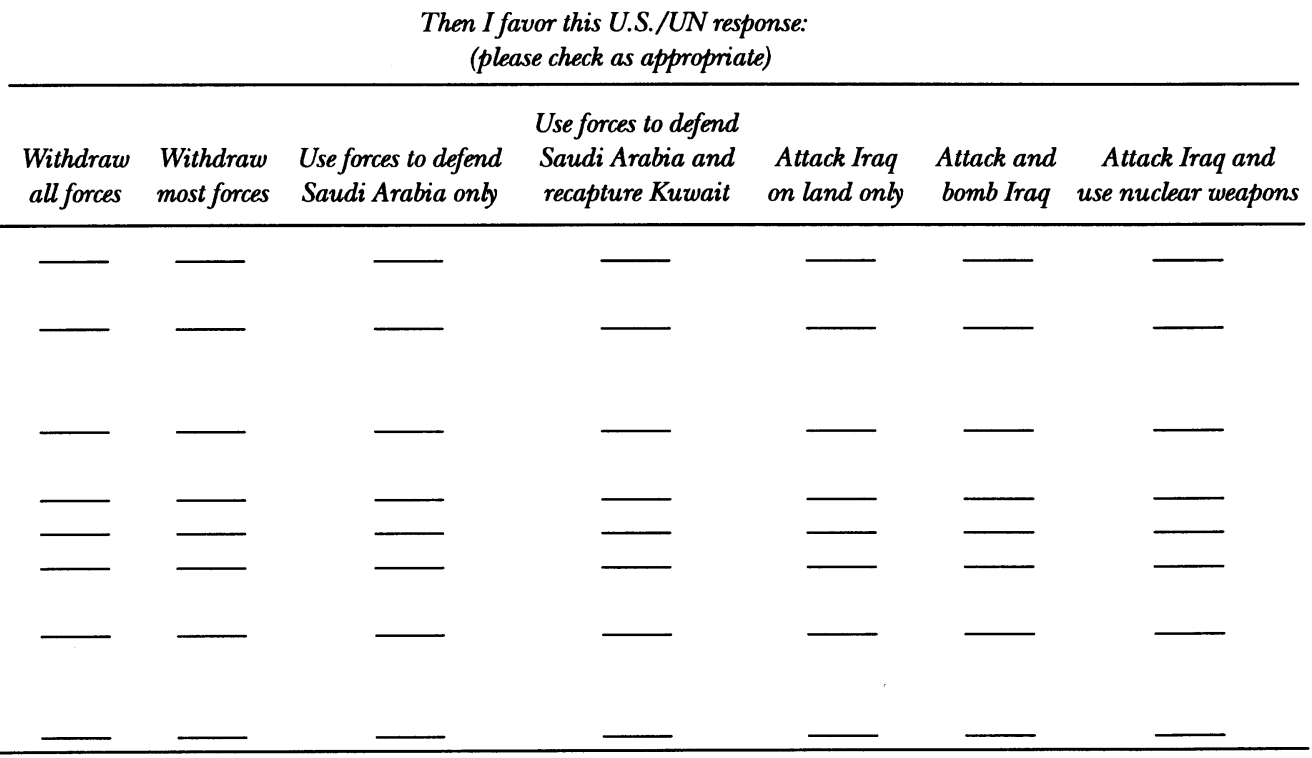

A. Iraq leaves Kuwait.

B. Iraq does not leave Kuwait by June 30, 1991.

C. Iraq does not let U.S. and other hostages go by June 30, 1991.

D. Iraq executes U.S. and other hostages.

E. Iraq attacks Israel.

F. Iraq invades Saudi Arabia.

G. Iraq uses chemical weapons in an invasion of Saudi Arabia.

H. Iraq invades Saudi Arabia and overwhelms U.S. and other defending forces. 
contrast to the integrative complexity rating measure, which often is correlated with length (see Suedfeld et al., 1992, p. 398).

\section{REFERENCES}

Adorno, T. W., Frenkel-Brunswik, E., Levinson, D. J., \& Sanford, R. N. (1950). The authoritarian personality. New York: Harper.

Altemeyer, B. (1981). Right-wing authoritarianism. Winnipeg: University of Manitoba Press.

Altemeyer, B. (1988). Enemies of freedom. San Francisco: Jossey-Bass.

Buchanan, P. J. (1991). Declare war, or come home. In J. Ridgeway (Ed.), The march to war (pp. 127-129). New York: Four Walls Eight Windows.

Buildup to war: American opinion on events in the Persian Gulf, January 1991. (1991, January). The Gallup Poll Monthly, pp. 2-35.

Brownmiller, S. (1992). Making female bodies the battle field. In A. Stiglmayer (Ed.), Mass rape: The war against women in BosniaHerzegovina (pp. 180-182). Lincoln: University of Nebraska Press.

Bush approval at 89 percent, highest in polling history. (1991, March). The Gallup Poll Monthly, pp. 2-4.

Canetti, E. (1962). Crowds and power. New York: Viking.

Cramer, J. (1990, September 10). Look who's antiwar now. Time, pp. 27-28.

Duncan, L. E., Peterson, B. E., \& Winter, D. G. (1997). Authoritarianism and gender roles: Toward a psychological analysis of hegemonic relationships. Personality and Social Psychology Bulletin, 23, 41-49.

Duncan, L. E., \& Stewart, A. J. (1995). Still bringing the Vietnam war home: Sources of contemporary student activism. Personality and Social Psychology Bulletin, 21, 914-924.

Edgington, T. J., \& Hutchinson, R. L. (1990). Fundamentalism as a predictor of cognitive complexity. Journal of Psychology and Christianity, 9, 47-55.

Elshtain, J. B. (1987). Women and war. New York: Basic Books.

Frenkel-Brunswik, E. (1949). Intolerance of ambiguity as an emotional and perceptual personality variable. Journal of Personality, 18, 108143.

Gallup, G. Jr., \& Newport, F. (1990, November). Wary Americans favor wait and see posture in Persian Gulf. Gallup Poll Monthly, pp. 13-16.

Granberg, D., \& Corrigan, G. (1972). Authoritarianism, dogmatism, and orientations toward the Vietnam war. Sociometry, 35, 468-476.

Gruenfeld, D. H. (1995). Status, ideology, and integrative complexity on the U.S. Supreme Court: Rethinking the politics of political decision making. Journal of Personality and Social Psychology, 68, 5-20.

Haddock, G., Zanna, M. P., \& Esses, V. M. (1993). Assessing the structure of prejudicial attitudes: The case of attitudes toward homosexuals. Journal of Personality and Social Psychology, 65, 11051118.

Hermann, M. G. (1980a). Assessing the personalities of Soviet Politburo members. Personality and Social Psychology Bulletin, 6, 332-352.

Hermann, M. G. (1980b). Explaining foreign policy behavior using personal characteristics of political leaders. International Studies Quarterly, 24, 7-46.

Hermann, M. G. (1983). Assessing personality at a distance: A profile of Ronald Reagan (Mershon Center Quarterly Report, Vol. 7, No. 6). Columbus: Mershon Center, Ohio State University.
Hermann, M. G. (1984). Personality and foreign policy decision making: A study of 53 heads of government. In D. A. Sylvan \& S. Chan (Eds.), Foreign policy decision-making: Perceptions, cognition, and artificial intelligence (pp. 53-80). New York: Praeger.

Hermann, M. G. (1987). Handbook for assessing personal characteristics and foreign policy orientations of political leaders. Columbus: Mershon Center, Ohio State University.

Izzett, R. R. (1971) . Authoritarianism and attitudes toward the Vietnam war as reflected in behavioral and self-report measures. Journal of Personality and Social Psychology, 17, 145-148.

Meloen, J. D. (1993). The F scale as a predictor of fascism: An overview of 40 years of authoritarianism research. In W. F. Stone, G. Lederer, \& R. Christie (Eds.), Strength and weakness: The authoritarian personality today (pp. 47-69). New York: Springer-Verlag.

Peterson, B. E., Doty, R. M., \& Winter, D. G. (1993). Authoritarianism and attitudes towards contemporary social issues. Personality and Social Psychology Bulletin, 19, 174-184.

Rank, O. (1914). Um städte werben [Conquest of cities]. Internationale Zeitschrift für ärtzliche Psychoanalyse, 2, 50-58.

Shevin-Coetzee, M., \& Coetzee, F. (Eds.). (1995). World War I and European society: A sourcebook. Lexington, MA: Heath.

Sidanius, J. (1985). Cognitive functioning and sociopolitical ideology revisited. Political Psychology, 6, 637-662.

Sidanius, J. (1988). Intolerance of ambiguity, conservatism, and racism-Whose fantasy, whose reality?: A reply to Ray. Political Psychology, 9, 309-316.

Smith, C. P. (Ed.). (1992). Motivation and personality: Handbook of the matic content analysis (pp. 393-400). New York: Cambridge University Press.

Snare, C. E. (1992). Personality and political postures: The case of the clerical rulers of Iran: I and II. Unpublished doctoral dissertation, Ohio State University.

Sorrentino, R. M., \& Short, J. C. (1986). Uncertainty orientation, motivation, and cognition. In R. M. Sorrentino \& E. T. Higgins (Eds.), Handbook of motivation and cognition (pp. 379-403). New York: Guilford.

Stagner, R. (1936). Fascist attitudes: An exploratory study. Journal of Social Psychology, 7, 309-319.

Sturman, T. S., \& Doty, R. M. (1092, July). Authoritarianism, power motivation, and abortion attitudes. Paper presented at the annual meeting of the International Society of Political Psychology, San Francisco.

Suedfeld, P., Bluck, S., Loewen, L. J., \& Elkins, D. J. (1994). Sociopolitical values and integrative complexity of members of student political groups. Canadian Journal of Behavioural Science, 26, 121-141.

Suedfeld, P., Tetlock, P. E., \& Streufert, S. (1992). Conceptual/integrative complexity. In C. P. Smith (Ed.), Motivation and personality: Handbook of thematic content analysis (pp. 393-400). New York: Cambridge University Press.

Tetlock, P. E. (1983). Cognitive style and political ideology. Journal of Personality and Social Psychology, 45, 118-126.

Winter, D. G. (1996). Personality: Analysis and interpretation of lives. New York: McGraw-Hill.

Received February 20, 1996

Revision accepted December 5, 1996 